\title{
PERFORMA GENOTIP IKAN TAMBAKAN Helostoma temminckii (CUVIER, 1829) POPULASI SUMATERA, JAWA DAN KALIMANTAN DENGAN METODE RANDOM AMPLIFIED POLYMORPHIC DNA (RAPD)
}

\author{
MH. Fariduddin Ath-thar ${ }^{1)^{*}}$, Intan Putriana ${ }^{2)}$, Dinar Tri Soelistyowati ${ }^{2)}$ dan Rudhy Gustiano ${ }^{1)}$ \\ ${ }^{1)}$ Balai Penelitian dan Pengembangan Budidaya Air Tawar Bogor \\ ${ }^{2)}$ Departemen Budidaya Periaran, Institut Pertanian Bogor \\ "e-mail: faridkkp@yahoo.com
}

\author{
ABSTRACT \\ Genotype performance of Tambakan, Helostoma temminckii (Cuvier, 1829) \\ from Sumatera, Java and Kalimantan Polulation using Random \\ Amplified Polymorphic DNA (RAPD)
}

\begin{abstract}
Tambakan, kissing gourami (Helostoma temminckii) is well known as a freshwater tropical species from Southeast Asia. In Indonesia, tambakan is an important commodity. However, total production of tambakan tends to decrease. Therefore, domestication has urgently to be done to solve the problem of Tambakan population. Three different tambakan populations from Sumatera, Java and Kalimantan were observed to find good genetic resources for culture activity. This study aimed to investigate the genetic variation of tambakan especially from West Java, Jambi, and South Kalimantan province using RAPD. The result showed that the highest polymorphism and heterozygosity was from South Kalimantan population among others. The three population observed had the fragment size ranged from 100- $2000 \mathrm{bp}$. The highest genetic distance was between Sumatera and Kalimantan (0,2877), while the lowest was between Kalimantan and Java $(0,1961)$.
\end{abstract}

Key words: Helostoma temminckii, genetic, heterozigosity, genetic relationship

\begin{abstract}
ABSTRAK
Ikan tambakan (Helostoma temminckii) adalah salah satu jenis ikan air tawar yang berasal dari wilayah tropis, tepatnya Asia Tenggara. Di Indonesia ikan tambakan merupakan salah satu ikan komoditas penting. Saat ini, jumlah produksi ikan tambakan cenderung menurun. Sehingga domestikasi sangat diperlukan untuk mengatasi masalah peneurunan populasi tambakan Tiga populasi ikan tambakan dari Sumatera, Jawa dan Kalimantan diobeservasi untuk mendapatkan sumber genetic terbaik yang dapat digunakan untuk kegiatan budidaya.. Penelitian ini bertujuan untuk mengidentifikasi keragaman genetika populasi ikan tambakan Jambi, Jawa Barat dan Kalimantan Selatan menggunakan metode RAPD. Hasil menunjukkan bahwa polimorfisme dan heterosigositas tertinggi terdapat pada populasi ikan tambakan Kalimantan Selatan jika dibandingkan dengan populasi ikan tambakan lainnya. Ukuran fragmen DNA teramplifikasi berkisar antara 100-2000 bp. Jarak genetik paling jauh adalah antara populasi tambakan Sumatera dengan Kalimantan $(0,2877)$, sedangkan jarak genetik terendah adalah tambakan Kalimantan dengan Jawa $(0,1961)$.
\end{abstract}

Kata kunci: Helostoma temminckii, genetik, heterosigositas, kekerabatan

\section{PENDAHULUAN}

Ikan Tambakan adalah salah satu potensi sumberdaya genetik (SDG) air tawar Indonesia yang mempunyai potensi untuk dikembangkan (Gustiano et al., 2015). Secara umum, keanekaragaman sumberdaya genetik terbagi menjadi sumberdaya genetik ikan alam liar yang belum dapat diadaptasikan dan sumberdaya genetik ikan yang sudah dapat dibudidayakan. Salah satu sumber daya genetik ikan liar yang sudah dapat diadaptasikan adalah ikan tambakan (Helostoma temminckii) (Gustiano et al., 2015). Ikan tambakan adalah salah satu jenis ikan air tawar yang berasal dari wilayah tropis, tepatnya Asia Tenggara. Ikan tambakan dibudidaya untuk 
diambil dagingnya di wilayah Asia Tenggara. Di Indonesia, ikan tambakan merupakan salah satu ikan bernilai ekonomi tinggi. Sebagai dampak dari popularitasnya sebagai ikan hias, ikan tambakan yang berukuran kecil sekitar $12-15 \mathrm{~cm}$ diekspor ke Negara seperti Jepang, Eropa, Amerika Utara, dan Australia (FAO, 2010). Diluar negeri, ikan tambakan berukuran $12-15 \mathrm{~cm}$ dijual dengan harga 3,00 - 6,00 USD/ ekor. Berdasarkan data DJPT KKP (2012) jumlah produksi ikan tambakan untuk konsumsi mulai mengalami penurunan. Pada tahun 2010 jumlah produksi ikan tambakan adalah 12914 ton dan menurun pada tahun 2011 menjadi sebesar 12063 ton, atau mengalami penurunan produksi sekitar 6,59\%.

Ikan tambakan merupakan ikan dengan pertumbuhan yang lambat dan FCR yang cukup tinggi, sehingga menjadi kendala bagi pembudidaya. Oleh karena itu, masyarakat kerap mengandalkan tangkapan dari alam. Penurunan populasi yang diakibatkan oleh eksploitasi yang berlebihan perlu dicegah, diantaranya dengan pengembangan budidaya ikan tambakan dan pencegahan kerusakan lingkungan. Untuk meningkatkan produksi ikan yang berkelanjutan perlu didukung oleh program pemuliaan atau perbaikan sediaan genetik yang unggul (Gjedrem, 2005). Habitat yang kurang memadai dapat menyebabkan perkembangan populasi ikan tertekan dan kemampuan reproduksi menurun. Ikan tambakan merupakan ikan omnivora yang bersifat bentopelagik (hidup di antara per-mukaan dan wilayah dalam perairan). Ikan ini tidak membuat sarang maupun merawat anaknya seperti Anabantidae lainnya (Rainboth, 1996).

Dunham (2011) menyatakan bahwa variasi genetik penting untuk menjamin fitness suatu spesies atau populasi terhadap perubahan lingkungan. Dewasa ini, secara genotip karakterisasi banyak dilakukan dengan menganalisis informasi polimorfisme materi DNA inti atau DNA mitokondria (Dunham, 2011). Informasi keragaman sumber daya genetic merupakan titik tolak dala me- lakukan program budidaya yang lestari melalui program pemuliaan. RAPD (Random Amplified Polymorphism DNA) melalui teknik PCR (Polymeras Chain Reaction) adalah salah satu cara untuk mengetahui ragam genotip (Dunham, 2011). Metode RAPD sangat baik digunakan untuk mendeteksi polimorfisme gen dalam jumlah besar karena primer oligonukleotida bisa teramplifikasi pada semua genom yang memiliki situs ikatan dalam reaksi PCR (Ali et al, 2004). Selain itu, RAPD mampu mendeteksi sekuen nukleotida hanya dengan menggunakan satu primer dan dapat digunakan tanpa mengetahui latar belakang genom sebelumnya.

Penelitian ini bertujuan untuk melakukan karakterisasi corak kera-gaman genotip ikan tambakan populasi Jambi, Jawa Barat dan Kalimantan Selatan dengan menggunakan metode RAPD.

\section{BAHAN DAN METODA}

Penelitian ini dilakukan pada bulan September - Oktober 2011 di Balai Penelitian dan Pengembangan Budidaya Air Tawar Bogor. Ikan tambakan yang dianalisis dikoleksi dari Balai Penelitian dan Pengembangan Budidaya Air Tawar Bogor berasal dari tiga lokasi yang berbeda yaitu Jawa (Jawa Barat) berasal dari kolam budidaya, Sumatera (Jambi) berasal dari kolam budidaya, dan Kalimantan (Kalimantan Selatan) berasal dari alam. Masing-masing populasi diambil 10 ekor.

\section{Ekstraksi DNA}

Bagian dari tubuh ikan yang diektraksi adalah potongan sirip dengan berat5-10 mg. Selanjutnya, sirip dibilas dengan akuades sebanyak dua kali kemudian dikeringkan dengan tisu. Sirip dimasukkan ke dalam tabung eppendorf kemudian ditambahkan 500 L larutan TNES Urea dan kemudian ditambahkan $10 \mathrm{~L}$ protein kinase lalu divortex hingga homogen dan diinkubasi selama 24 jam pada suhu $37^{\circ} \mathrm{C}$. Selanjutnya, 
campuran tersebut divortex dan ditambahkan dengan larutan Phenolchloroform sebanyak 1000 L lalu divortex sampai homogen dan disentrifuse dengan kecepatan $10.000 \mathrm{rpm}$ selama 10 menit. Supernatan yang terbentuk diambil dan dipindahkan ke tabung yang baru lalu ditambahkan 10 L natrium asetat dan 1000 L Etanol. Setelah itu tabung dikocok hingga terlihat benang halus berwarna putih. Selanjutnya tabung disentrifuse dengan kecepatan 10.000 rpm selama 10 menit. Setelah di-sentrifuse maka akan terbentuk endapan DNA. Endapan DNA dipisahkan dari larutan dan dikering anginkan. Setelah itu, DNA ditambahkan 100 L Rehydration Solution DNA (Nugroho et al., 1997).

\section{Amplifikasi DNA dengan teknik PCR (Polymerase Chain Reaction)}

Amplifikasi PCR dilakukan dengan cara 1 unit dry taq produk Promega ditambahkan dengan 1,5 L DNA dan 2

$\mathrm{L}$ primer. Primer yang digunakan adalah OPA 2, OPC 2, dan OPC 5. Selanjutnya ditambahkan akuades hingga total volume menjadi 25 L. Setelah itu dimasukkan ke mesin PCR dengan 35 siklus, yaitu pre denaturasi pada $94^{\circ} \mathrm{C}$ selama 2 menit, denaturasi pada suhu 94 ${ }^{\circ} \mathrm{C}$ selama 1 menit, annealing pada suhu $36{ }^{\circ} \mathrm{C}$ selama 1 menit, elongasi pada suhu $72{ }^{\circ} \mathrm{C}$ selama 2,5 menit, elongasi akhir pada suhu $72{ }^{\circ} \mathrm{C}$ selama 7 menit, dan proses penstabilan pada suhu $4{ }^{\circ} \mathrm{C}$ selama 3 menit (Nugroho et al., 1997).

\section{Elektroforesis}

Gel agarose dibuat terlebih dahulu dengan konsentrasi 2\% dengan mencampurkan bubuk Agarose dengan larutan TBE yang diaduk dengan magnetic stirrer dan dipanaskan pada suhu $150^{\circ} \mathrm{C}$ sampai homogen. Selanjutnya ditambahkan Etidium bromida sebanyak $10 \mathrm{~L}$.
Agarose dituang dalam cetakan yang berlubang. Gel Agarose diletakkan pada alat elektroforesis sampai gel terendam. Sekuen DNA sebanyak 3 L ditambahkan dengan Loading Dye $(50 \mathrm{mM}$ EDTA, 30\% gliserol, 0,25\% bromophenol biru, dan $0,25 \%$ xylene cyanol) sebanyak 3 L kemudian dimasukkan ke dalam lubang cetakan gel dengan mikrotipe.elektroforesis berlangsung selama 30 menit pada tegangan 100 volt dan suhu ruang. Selanjutnya, gel Agarose diamati di atas lampu ultraviolet dan didokumentasikan dengan kamera polaroid khusus (Nugroho et al., 1997).

\section{Analisis Data}

Keragaman genetik dianalisis dengan menggunakan program TFPGA (Tools for Population Genetic Analysis) (Nei dan Tajima, 1981). Hubungan kekerabatan interpopulasi dianalisis berdasarkan jarak genetik dengan program UPGMA (Unweight Pair Methods Arithmetic) menurut Wright (1978) yang dimodifikasi oleh Rogers (1972).

\section{HASIL DAN PEMBAHASAN}

Penelitian observasi karakterisasi genetic pada ikan tambakan dengan menggunakan metode RAPD ini menggunakan lima primer yaitu OPA-2, OPA-4, OPA-7, OPC- 2 dan OPC-5. Hasil amplifikasi paling optimal ditunjukkan pada tiga primer yaitu OPA-2, OPC- 2, dan OPC-5.

\section{Profil RAPD}

Keanekaragaman profil RAPD meliputi jumlah fragmen dan ukuran fragmen DNA. Hasil amplifikasi dengan menggunakan tiga primer (OPA-2, OPC- 2, dan OPC-5) menunjukkan hasil yang bervariasi (Tabel 1). Amplifikasi DNA pada tiga populasi ikan tambakan dapat dilihat pada Gambar 1-3. 


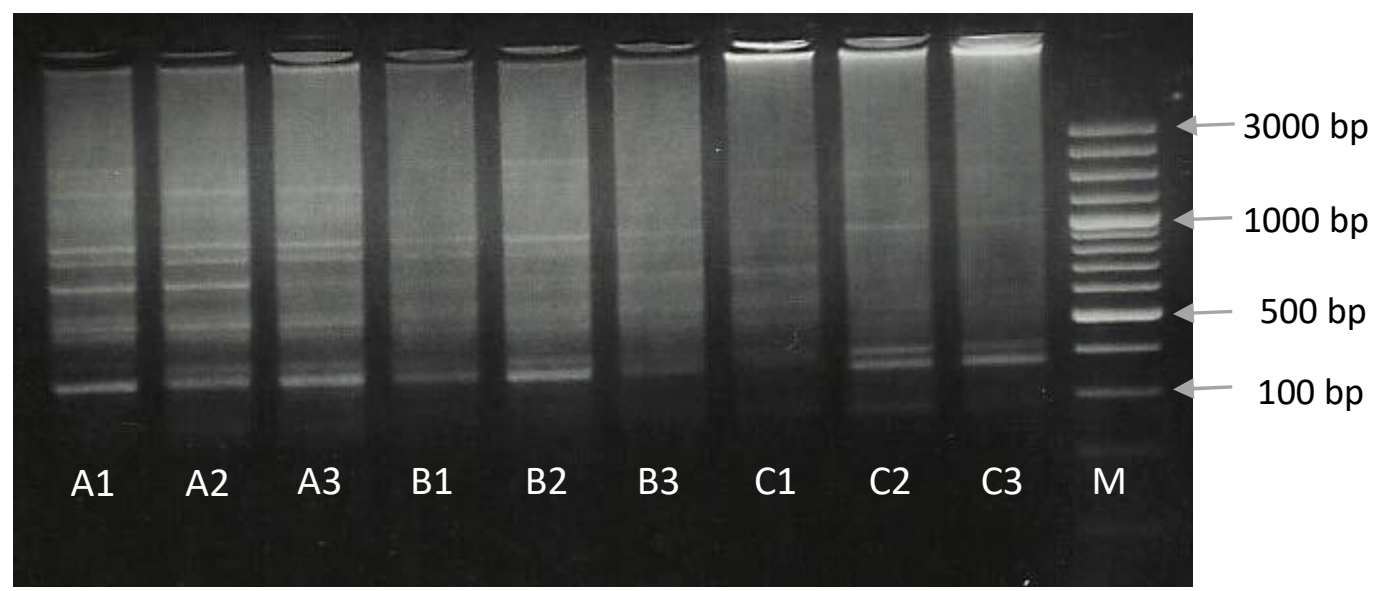

Keterangan: A1- A3: Ikan Tambakan Populasi Jambi, B1-

B3: Ikan Tambakan Populasi Jawa Barat, C1-C3:

Ikan Tambakan Populasi Kalimantan Selatan, M:

Marker

Gambar 1. Amplifikasi OPA-2 pada ikan Tambakan populasi Jambi, Jawa Barat dan Kalimantan Selatan

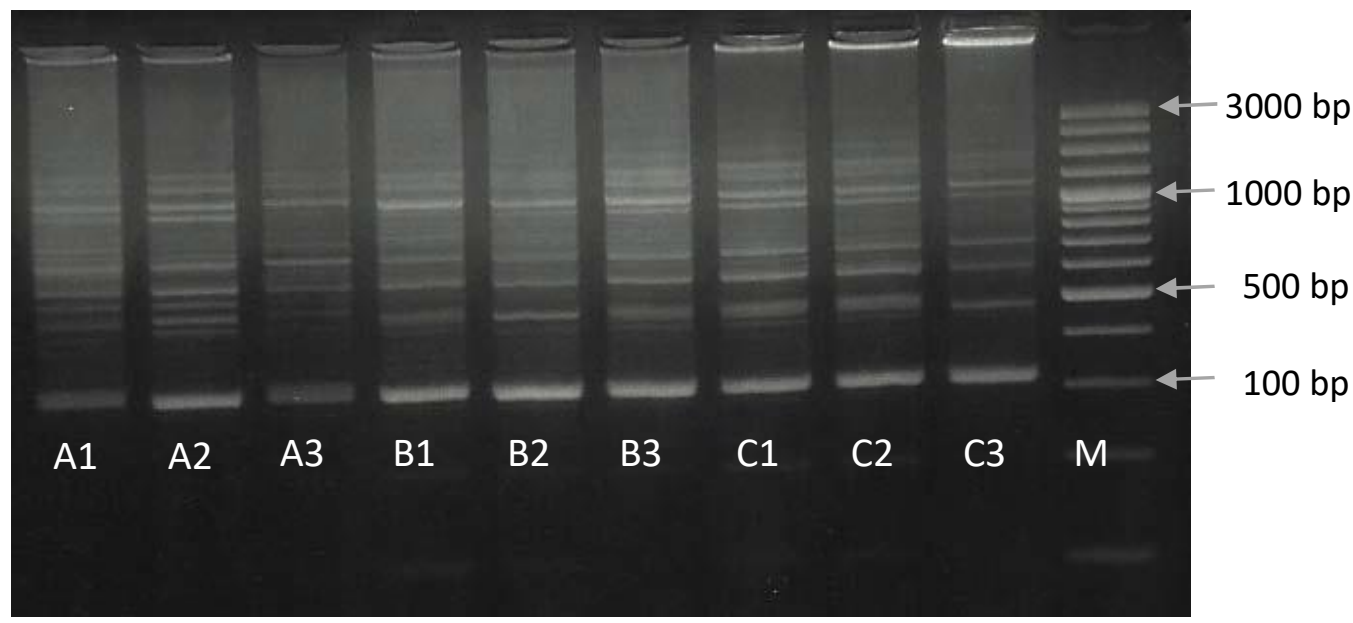

Keterangan: A1- A3: Ikan Tambakan Populasi Jambi,

B1-B3: Ikan Tambakan Populasi Jawa Barat,

C1-C3: Ikan Tambakan Populasi Kalimantan

Selatan, M: Marker

Gambar 2. Amplifikasi OPC-2 pada ikan Tambakan populasi ikan Tambakan populasi Jambi, Jawa Barat dan Kalimantan Selatan

Jumlah fragmen ikan tambakan Jawa dan Kalimantan memiliki jumlah yang sama yaitu 13-22, sedangkan jumlah fragmen pada ikan tambakan Sumatera berkisar antara 19-24. Ukuran fragmen pada setiap populasi berkisar antara 1002000 bp. Namun, ukuran fragmen pada setiap populasi memiliki nilai yang sama berkisar antara 100-2000 bp. 



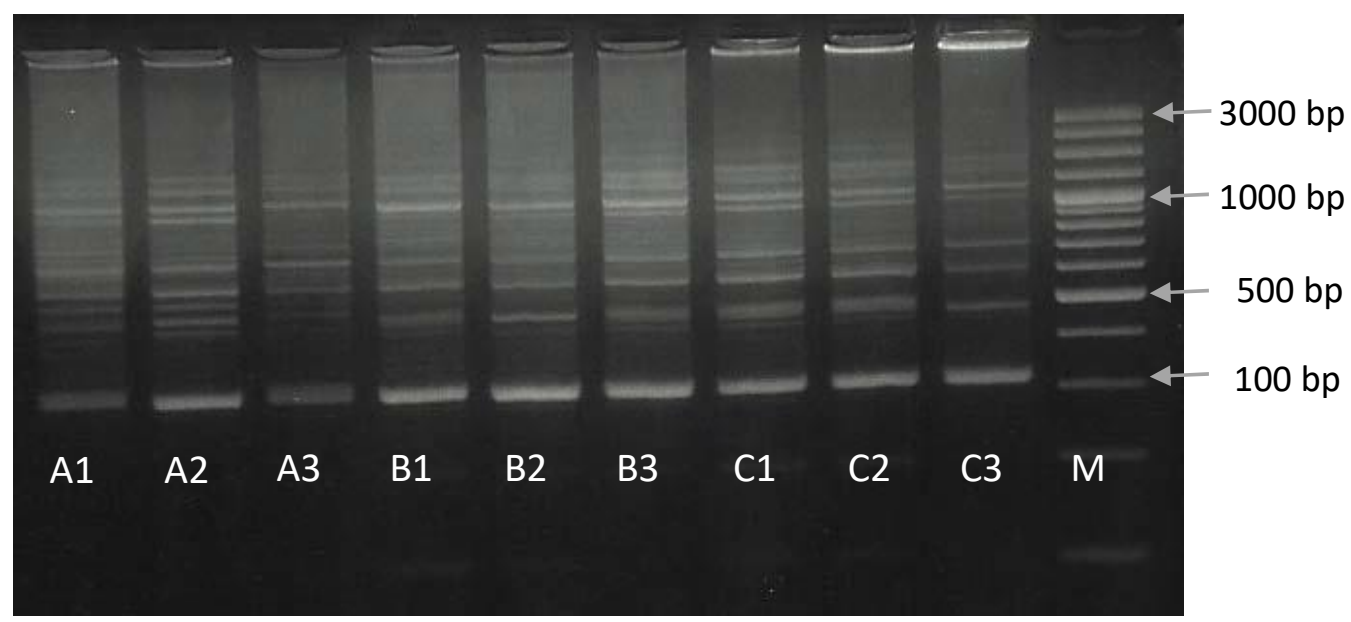

Keterangan: A1- A3: Ikan Tambakan Populasi Jambi, B1-B3: Ikan Tambakan Populasi Jawa Barat, C1-C3: Ikan Tambakan Populasi Kalimantan Selatan, M: Marker

Gambar 3 Amplifikasi OPC-5 pada ikan Tambakan populasi ikan Tambakan populasi Jambi, Jawa Barat dan Kalimantan Selatan

Tabel 1. Profil DNA ikan Tambakan populasi ikan Tambakan populasi Jambi, Jawa Barat dan Kalimantan Selatan

\begin{tabular}{ccc}
\hline Populasi Ikan Tambakan & Jumlah Fragmen & Kisaran ukuran \\
\hline Sumatera & $19-24$ & $100-2000 \mathrm{bp}$ \\
Jawa & $13-22$ & $100-2000 \mathrm{bp}$ \\
Kalimantan & $13-22$ & $100-2000 \mathrm{bp}$ \\
\hline
\end{tabular}

Hasil amplifikasi setiap primer memiliki karakter yang berbeda sehingga jumlah dan ukuran fragmen yang muncul pun berbeda. Pemilihan primer pada RAPD berpengaruh terhadap polimorfisme fragmen yang dihasilkan karena setiap primer memiliki situs penempelan sendiri sehingga fragmen dari DNA yang diamplifikasi oleh primer berbeda menghasilkan polimorfik dengan jumlah fragmen dan berat molekul berbeda (Dieffenbach \& Dveksler, 2003).

\section{Polimorfisme dan Heterosigositas}

Persentase polimorfisme dan heterosigositas dianalisis dengan menggunakan program TFPGA. Data persentase polimorfisme dan heterosigositas selengkapnya disajikan pada Tabel 2 . Persentase polimorfisme dari tiga populasi ikan tambakan berkisar antara 57,1429\%-60,7143\%. Persentase polimorfisme tertinggi terdapat pada ikan tambakan Kalimantan yaitu sebesar $60,7143 \%$, sedangkan polimorfisme terendah terdapat pada ikan tambakan Sumatera dan Jawa dengan nilai yang sama yaitu $57,1429 \%$. Nilai heterosigositas berkisar antara 0,2259 sampai 0,2478 . Nilai heterosigositas tertinggi terdapat pada populasi ikan tambakan kalimantan sebesar 0,2478, sedangkan nilai heterosigositas terendah terdapat pada populasi ikan tambakan Sumatera sebesar 0,2259 .

Tabel 2. Persentase polimorfisme dan heterosigositas ikan Tambakan populasi ikan Tambakan populasi Jambi, Jawa Barat dan Kalimantan Selatan

\begin{tabular}{ccc}
\hline Populasi Ikan Tambakan & Polimorfisme (\%) & Heterosigositas \\
\hline Sumatera & 57.1429 & 0.2259 \\
Jawa & 57.1429 & 0.2324 \\
Kalimantan & 60.7143 & 0.2478 \\
\hline
\end{tabular}


Tabel 3. Uji perbandingan berpasangan Fst dari rata-rata 3 lokus ikan Tambakan populasi Jambi, Jawa Barat dan Kalimantan Selatan

\begin{tabular}{ccc}
\hline Populasi Ikan Tambakan & Polimorfisme $(\%)$ & Heterosigositas \\
\hline Sumatera & 57.1429 & 0.2259 \\
Jawa & 57.1429 & 0.2324 \\
Kalimantan & 60.7143 & 0.2478 \\
\hline
\end{tabular}

Persentase polimorfik tertinggi diperoleh pada populasi Kalimantan yaitu $60,7143 \%$, sedangkan polimorfik ikan tambakan Sumatera dan Jawa memiliki nilai yang sama yaitu $57,1429 \%$. Nilai heterosigositas tertinggi diperoleh populasi Kalimantan sebesar 0.2478, sedangkan nilai terendah pada populasi Sumatera sebesar 0.2259. Heterozigositas menunjukkan potensi kemampuan adaptasi terhadap lingkungannya karena semakin tinggi heterozigositas maka semakin banyak gen yang terlibat dalam menyumbangkan kebugaran suatu populasi. (Kapsucinski dan Jacobson, 1987; Kirpichnikov, 1981; Tave, 1993). Kondisi keragaman genetik dipengaruhi oleh ukuran populasi dan sistem pengembangbiakan yang dilakukan. Ukuran populasi yang besar dan persilangan bebas (acak) dapat mempertahankan ragam genetic (Falconer dan Mackay, 1996). Tingginya keragaman genetik ikan tambakan diduga karena ikan tambakan memiliki tingkat migrasi yang lebih tinggi dibandingkan ikan air tawar lainnya sehingga peluang adanya persilangan dengan populasi (stok) yang lainnya semakin besar pula. Ikan tambakan merupakan jenis ikan yang tidak merawat anaknya sehingga memungkinkan ikan tambakan untuk melakukan migrasi dengan jarak yang cukup jauh. Populasi dengan laju migrasi yang sempit atau jarak yang pendek mempunyai heterosigositas rendah dibandingkan dengan populasi yang mempunyai migrasi luas dan bersifat terbuka.

\section{Uji Perbandingan Berpasangan Fst}

Secara statistik dengan menggunakan uji perbandingan berpasangan Fst (Tabel 5) menunjukkan tidak terdapat perbedaan yang nyata antara ketiga populasi ikan tambakan $(\mathrm{P}>0,05)$.

\section{Jarak Genetik}

Jarak genetik interpopulasi menggambarkan status kekerabatan antar populasi ikan tambakan. Jarak genetik tertinggi adalah antara populasi Sumatera dengan Kalimantan sebesar 0,2877, sedangkan jarak genetik terendah adalah 0,1961 yaitu antara populasi Kalimantan dengan Jawa.
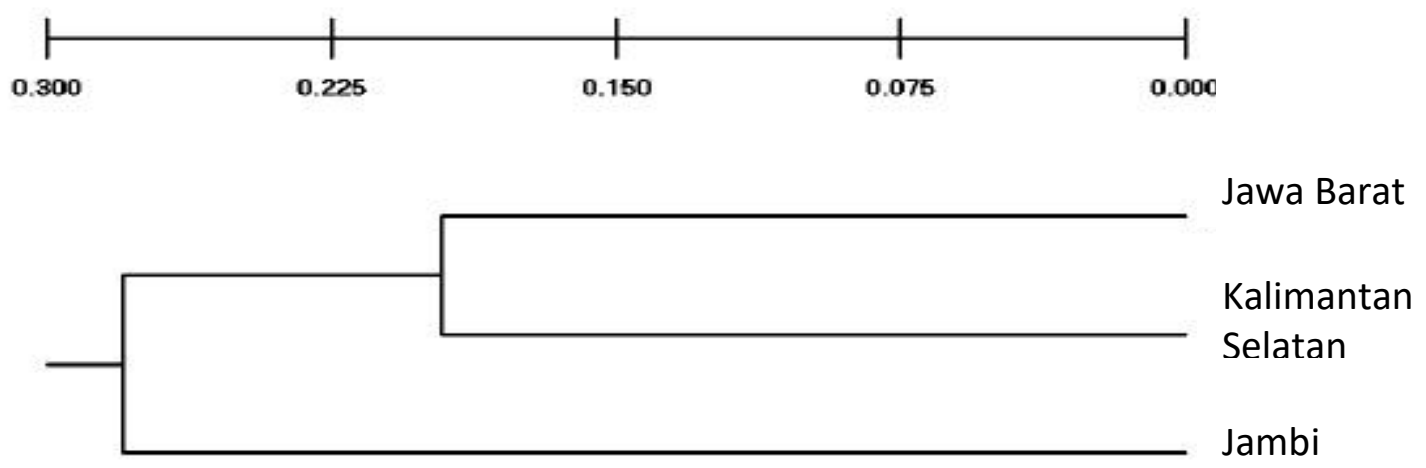

Gambar 4. Dendrogram hubungan kekerabatan ikan Tambakan populasi Jambi, Jawa Barat dan Kalimantan Selatan 
Dendrogram pada Gambar 4 memperlihatkan hubungan terdekat adalah antara populasi Jawa dengan Kalimantan, sedangkan hubungan terjauh adalah antara kedua populasi tersebut dengan populasi Sumatera. Jarak genetik antara populasi ikan tambakan Sumatera dan Kalimantan lebih tinggi yaitu 0,2877 dibandingkan dengan tambakan dari Jawa menandakan bahwa kedua populasi tersebut memiliki hubungan kekerabatan yang lebih jauh dibanding populasi lainnya.

\section{KESIMPULAN DAN SARAN}

\section{Kesimpulan}

Polimorfisme dan heterosigositas tertinggi terdapat pada populasi ikan tambakan Kalimantan. Ukuran fragmen pada setiap populasi berkisar antara 1002000 bp. Jarak genetik tertinggi adalah antara populasi Jawa dengan Kalimantan sebesar 0,2877, sedangkan jarak genetik terendah adalah 0,1961 yaitu antara populasi Kalimantan dengan Sumatera.

\section{Saran}

Untuk penelitian selanjutnya disarankan untuk menambah jumlah populasi ikan yang diobservasi dari lokasi lain sehingga hasilnya lebih representatif.

\section{DAFTAR PUSTAKA}

Ali, B.A., Huang T.H, Qin D. N., Wang X.M. 2004. A review of random amplified polymorphic DNA (RAPD) markers in fish research. Reviews in Fish Biology and Fisheries 14: 443453

Dieffenbach, C.W dan Dveksler G. S. 2003. PCR primer: a laboratory manual. Cold Spring Harbor Laboratory Press. 520 pp
Direktorat Jendral Perikanan Tangkap. 2012. Statistik perikanan tangkap Indonesia 2012. Kementerian Kelautan Perikanan

Dunham, R.A. 20011. Aquaculture and fisheries biotechnology: Genetic Approach. CABI publishing, Cambridge, USA. P: 85-99.

FAO. 2010. Helostoma temminckii (Cuvier, 1829). Species fact sheet. FAO, Roma

Falconer, F.S. dan Mackay T.F.C. 1996. Introduction to quantitative genetics. Longman England. 464pp

Gjedrem, T. 2005. Selection and breeding programs in aquaculture. Springer. New York. P: 251-277

Gustiano R., Kusmini I.I., Ath-thar M.H.F. Mengenal sumber daya genetik ikan spesifik lokal air tawar indonesia untuk pengembangan budidaya. PT Penerbit IPB Press.

Kapuscinski, A.R dan Jacobson L.D. 2007. Genetic guideline for fisheries management. University of Minnesota, Minnesota Sea Grant Collge Program. Sea Grant Research Report 17, 1-66

Kirpichnikov, V.S. Genetic Bases of Fish Selection. Springer Verlag Berlin. 410pp

Nei, M and Tajima F.. 1981. DNA Polymorphism detectable by resctriction endonuclease. Genetics 97: 146-163. 
Nugroho, E., M. Takagi, N. Taniguchi. 1997. Practical manual on detection of DNA polymorphism in fish population study. Bulletin of Marine Sciences and Fisheries 17:109-129.

Rainboth, W.L. 1996. FAO species identification field guide for fishery purposes. Fishes of the Cambodian Mekong. Rome, FAO. 265 pp.
Tave, D. 1993. Genetics for fish hatchery managers. Kluwer Academic Publications. Netherland. 415pp 